\title{
IT crime: a virtual threat with real consequences
}

\author{
Taulan Osmanovich Boziev ${ }^{1 *}$, Aleksey Viktorovich Korotkov ${ }^{1}$, Mayya Nikolaevna \\ Sipyagina $^{1}$, and Manas Kapasovich Intykbaev ${ }^{2}$ \\ ${ }^{1}$ State Institute of Economics, Finance, Law and Technologies, Gatchina, Leningrad region, Russia \\ ${ }^{2}$ Central Kazakhstan Academy, Department of Criminal Law and Procedure, Almaty, Kazakhstan
}

\begin{abstract}
The paper is focused on the problem of IT-crime development in Russia against the background of a significant increase in its indicators. Analysis of the current state of IT crime, identification of its causes and growth factors, problems of countering this type of crime. The study was carried out using general scientific methods (analysis and synthesis, observation, logical method, content analysis of the media), private scientific methods: questioning and survey, as well as the method of criminal statistics. The study made it possible to identify the features of the restructuring of modern crime and its factors; correlate the problem of the development of IT crime, including with the shortcomings of the functioning of the penal system revealed in the media; analyze and substantiate the proposed methods of combating IT crime. Substantiated a group of factors that currently have a significant impact on the development of IT crime; the revealed problem of the development of IT-criminality in places of deprivation of liberty is analyzed: the reasons and methods of counteraction. The conclusion is made about the inexpediency of methods of technical intervention in universal access to communication services in local territorial areas that require significant budgetary investments. According to the study, the key role in normalizing the situation in the penitentiary system still belongs to the staff of institutions, and the creation of the most effective ways to stimulate law-abiding behavior.
\end{abstract}

Keywords: IT crime, criminal statistics, factors of crime, penal system, "call center"

\section{Introduction}

At present, according to criminal statistics presented on the official websites of the Main Information and Analysis Center of the Ministry of Internal Affairs of Russia and the Judicial Department at the Supreme Court of the Russian Federation, the crime rate in Russia is decreasing annually. Since 2015, there has been a systematic decrease in the number of registered crimes, only in 2019 a slight increase was noticed in comparison with 2018, but in relation to the earlier period, this figure is still lower. The number of persons who have committed crimes, the number of convicts is decreasing (Table 1).

\footnotetext{
${ }^{*}$ Corresponding author: boziev1975@yandex.ru
} 
Table 1. Analysis of crime's amount.

\begin{tabular}{|c|c|c|c|}
\hline Year & $\begin{array}{c}\text { Total crimes registered, } \\
\text { thous. }\end{array}$ & $\begin{array}{c}\text { Persons who have } \\
\text { committed crimes, total }\end{array}$ & $\begin{array}{c}\text { Total convicted } \\
\text { persons }\end{array}$ \\
\hline 2015 & 2352.1 & 1075333 & 733607 \\
\hline 2016 & 2160 & 1015875 & 740380 \\
\hline 2017 & 2058.5 & 967103 & 697134 \\
\hline 2018 & 1992 & 931107 & 658291 \\
\hline 2019 & 2024.3 & 884661 & 598214 \\
\hline
\end{tabular}

According to the current data of the Main Information and Analysis Center of the Ministry of Internal Affairs of Russia for the first half of 2020, the situation as a whole remains the same, the statistics correspond to the previous period. And this is despite the pandemic! At the same time, some regions have seen an unprecedented increase in the number of crimes committed. According to Rossiyskaya Gazeta in November 2020, Sevastopol (+44.3\%), St. Petersburg $(+24.9 \%)$ and the Leningrad Region $(+13.1 \%)$ became the leaders among the subjects of the Russian Federation in terms of the rate of crime growth since the beginning of the year [1].

The structure of crime is changing. The number of crimes against the person is systematically decreasing in comparison with the same period of the previous year (by $8 \%$ ), the number of crimes committed with the use of weapons - by $10.1 \%$, banditry - by $20.2 \%$, robberies - by $11.4 \%$, thefts - by $2.9 \%$.

The number of crimes committed in public places decreased by $10.6 \%$, including on the streets, squares, parks and squares - by $10.2 \%$. Street banditry decreased by $23.6 \%$, robberies - by $20.7 \%$, thefts - by $19.6 \%$, theft of vehicles - by $28.7 \%$.

\section{Statement of the problem}

At the same time, according to the Ministry of Internal Affairs of Russia, the growth of IT crime continues to be a significant factor that has a negative impact on the crime situation in the country. In January-June 2020, it amounted to $91.7 \%$ compared to the same period last year, and the share of these illegal acts in the overall structure of crime reached $22.3 \%$.

In recent years, there has been a restructuring of crime. Not losing its relevance, the selfish motive is now achieved not through street, open, violent attacks, but in a way much more "safe" for the offender, not requiring the use of violence [2].

Meanwhile, in the media more and more information appears that the subjects of IT crimes are often convicts who are in places of deprivation of liberty, which is surprising, because according to the Internal Regulations of Correctional Institutions, mobile communications and communications are included in the list of prohibited items.

Nevertheless, this problem is recognized not only by journalists, but also by law enforcement agencies. In 2020, another journalistic investigation by Eduard Petrov, "A Call from a Detention Center", appeared on the Internet, in which not only journalists, but also employees of the Investigative Committee of the Russian Federation participated. Later, the discussion of this issue was carried out in the program "60 minutes" on the TV channel "Russia 1".

The revealed facts of the "prison business", the financial level reached by the "call centers" in prisons, as well as the corruption of the Federal Penitentiary Service of Russia stirred up the entire public. 


\section{$3 \quad$ Results}

As a result of the study, it is possible to determine the factors in the development of IT crimes.

Improvement of technical equipment, both of streets and houses: installation of intercoms, CCTV cameras, barriers, and citizens themselves. Of course, all this "interferes" with a street criminal, contributes to his rapid exposure and investigation [3].

That is why the development of IT technologies has the opposite negative meaning, which also contributes to the restructuring of crime, as it allows the use of modern technological progress in the interests of criminals, and not to use violent methods of committing a crime. The so-called "telephone fraud" is currently gaining unprecedented momentum. Fraudsters daily develop new schemes for working with gullible citizens, posing as bank employees, calling from multi-channel phones, using various methods of psychological attacks, offering to make various electronic transactions, and so on. The victims are not only the victimized categories of persons (pensioners, people of the older generation), but sometimes even law enforcement officers. The amount of damage for the victim varies from several thousand to several million rubles.

The third factor is that this crime has an extremely high level of latency. According to experts in the field of IT technologies, the real number of crimes committed in the Russian Federation is more than five times higher than the official statistics [4]. Moreover, the concealment of crimes is observed both on the part of the victims and on the part of law enforcement agencies. The reasons for the latency are clear: extremely difficult detection, low amount of damage, the unwillingness of the victim to admit his credulity.

As for the penitentiary system, the response from the Federal Penitentiary Service of Russia has already followed. The solution to this problem is currently one of the main tasks of the service, set, including by the Security Council of the Russian Federation. In various territorial bodies of the Federal Penitentiary Service, preventive measures are being taken to conduct explanatory work with convicts through personal conversations, campaign posters, special control over persons prone to telephone fraud, and ensuring their employment.

As reported in the summer of 2020 by the press bureau of the Federal Penitentiary Service of Russia, today the most common way of delivering mobile phones to places of detention is to transfer them through the main fence [5]. According to departmental statistics, about $60 \%$ of mobile phones are confiscated when irresponsible citizens try to deliver them to pre-trial detention centers and correctional colonies. So, in 2019, when cyber criminals tried to deliver cell phones to penal institutions, more than 31 thousand mobile phones were seized, in 2018 - over 29 thousand. In total, in 2019, 56,249 mobile communication devices were seized from the institutions of the penal system, in 2018 - 64,004 units.

The Ministry of Internal Affairs of the Russian Federation proposed to install special "blockers" of a cellular signal in each correctional institution, as well as to develop a special application in the database of which you can enter the numbers of "fraudulent" phones [6].

An alternative solution was the introduction in January 2020 for consideration by the State Duma of draft law No. 876381-7 “On Amendments to Certain Legislative Acts of the Russian Federation regarding the termination of the provision of communication services on the territory of institutions executing criminal sentences in the form of imprisonment and places of detention under guards" [7].

The essence of the amendments is that special equipment is installed on the territory of a correctional institution or a pre-trial detention center, which makes it possible to determine that a call is being made from a particular number. Having fixed an unauthorized call, the head of the institution appeals to the head of the territorial body of the Federal Penitentiary Service, and he, in turn, to the telecom operator, who, according to his motivated statement, blocks a specific number. 
The bill was approved by the Government of the Russian Federation and 30.09.2020 was adopted at first reading.

Unfortunately, the initiators of the bill, who, although they have secured the support of representatives of the Federal Penitentiary Service itself, seem to have an extremely idealized idea of how correctional institutions actually function. At the same time, according to the Kommersant newspaper, the management of the Federal Penitentiary Service plans independent measures to combat cell phones in the institutions of the penal system, for which it is necessary to install high-tech equipment in cooperation with the state corporation Rostech [8], which will jam the signal of cellular operators in the field. However, its installation, of course, requires huge budgetary funding.

For this study, we surveyed the employees of one of the correctional institutions located in the city of St. Petersburg, on the subject of what measure of combating the use of mobile communications in places of detention they consider the most effective. The results were striking. About $85 \%$ of employees are sure that only an employee of the institution can be the main way to counter this phenomenon. Thorough conduct of search activities, wellorganized operational-search work, educational, preventive work with convicts, agitation of law-abiding behavior, a flexible system of incentives and penalties, anti-corruption orientation of the institution's employees, careful and conscientious performance of official duties, control by management, reducing the volume of paperwork - these are the ingredients that employees believe are the key to a successful and effective fight against telephone fraud in prisons.

\section{Conclusion}

Analyzing all the proposed methods of combating telephone fraud in prisons, we can conclude that today none of them can be considered successful.

In our opinion, it is necessary to expand the technological and procedural capabilities of law enforcement agencies to search for and solve this type of crime. It is inappropriate, in our opinion, to spend additional budgetary funds on technical devices without changing the internal legal consciousness of employees, without instilling intolerance to corruption and dishonest performance of official duties.

The article presents the author's position on the problem of spreading and countering IT crime. The inexpediency of the use of technical means for the repayment of cellular communications in places of confinement requiring serious financial investments is substantiated.

The practical significance lies in the possibility of increasing the efficiency of the mechanism for countering IT-crime by a more thorough study of the factors of this type of crime.

\section{References}

1. Peterburg i Sevastopol stali liderami po rostu prestupnosti [Saint Petersburg and Sevastopol have become leaders in the crime growth] (2020). Accessed on: March 21, 2021. [Online]. Available: http:https://rg.ru/2020/11/25/reg-ufo/peterburg-i-sevastopolstali-liderami-po-rostu-prestupnosti.html

2. S.F. Milyukov, Rus. Crim. View 1, 356-362 (2015)

3. T.O. Boziev, M.N. Sipyagina, Kriminologiya: uchebnoe posobie [Criminology: study guide] (Publishing house GTEFPT, Gatchina, 2016) 
4. A.A. Bordyugovskaya, I.A. Balashova, $K$ voprosu o primenenii ugolovno-pravovykh norm $v$ sfere okhrany kompyuternoi informatsii [On the question of the application of criminal law in the field of computer information protection], in Novellas of Law and Politics: Proc. All-Russian Scientific and Practical Conference, February 28, 2016, Gatchina (State Institute of Economics, Finance, Law and Technology, Gatchina, 2016)

5. FSIN rasskazala, kak telefony popadayut v kolonii [The Federal Penitentiary Service told how phones get to the colonies] (2020). Accessed on: March 21, 2021. [Online]. Available: https://ria.ru/20200724/1574847335.html

6. MVD reshilo zaglushit sotovuyu svyaz v tyurmakh Chem opasny call-tsentry v mestakh lisheniya svobody [The Ministry of Internal Affairs decided to shut down cellular communication in prisons] (2019). Accessed on: March 21, 2021. [Online]. Available:

https://www.rbc.ru/technology_and_media/06/11/2019/5dc17fae9a7947d6626ac54c?fr om=newsfeed

7. O vnesenii izmenenii v otdelnye zakonodatelnye akty Rossiiskoi Federatsii v chasti prekrashcheniya okazaniya uslug svyazi na territorii sledstvennykh izolyatorov i uchrezhdenii, ispolnyayushchikh ugolovnye nakazaniya v vide lisheniya svobody [On amendments to certain legislative acts of the Russian Federation regarding the termination of the provision of communication services in the territory of pre-trial detention centers and institutions that execute criminal penalties in the form of deprivation of liberty] (2020). Accessed on: March 21, 2021. [Online]. Available: https://sozd.duma.gov.ru/bill/876381-7

8. FSIN khochet likvidirovat tyuremnye "koll-tsentry" [The Federal Penitentiary Service wants to eliminate prison "call centers"] (2020). Accessed on: March 21, 2021. [Online]. Available: https://www.kommersant.ru/doc/4511968 